\title{
Distribution of genetic polymorphism of aldehyde dehydrogenase-2 (ALDH2) in Indonesian subjects
}

\author{
Septelia Inawati Wanandi
}

\begin{abstract}
Abstrak
Aldehida dehidrogenase $(A L D H)$ merupakan enzim yang berperan penting pada metabolisme alkohol. Penurunan aktivitas enzim ALDH lebih berpengaruh pada hipersensitivitas terhadap alkohol daripada penurunan aktivitas alkohol dehidrogenase. Enzim ALDH terdapat dalam beberapa isozim. Di antara isozim-isozim ini, ALDH2 merupakan isozim utama yang mempunyai afinitas yang sangat tinggi terhadap asetaldehida. Dari hasil penelitian terdahulu diketahui bahwa defisiensi ALDH2 dapat diturunkan. Polimorfisme fungsional gen ALDH2 telah diteliti pada satu nukleotida di dalam kodon ke 487. Pada gen yang atipik, kodon ini terdiri dari nukleotida AAA yang menyandi asam amino lisin, sebagai pengganti GAA untuk asam glutamat pada gen wild type. Pada penelitian ini telah dianalisis polimorfisme genetik gen ALDH2 di antara 100 mahasiswa Indonesia dengan menggunakan DNA genom yang diekstraksi dari akar rambut. Untuk tujuan tersebut digunakan metode PCR (Polymerase Chain Reaction) dan RFLP (Restriction Fragment Length Polymorphism). Tiga primer oligonukleotida dirancang untuk dua tahap PCR. Primer reverse $(R)$ dikonstruksi sedemikian rupa sehingga tidak $100 \%$ komplementer dengan untai DNA cetakan, dengan tujuan agar dihasilkan situs restriksi EcoRI yang mencakup nukleotida yang variabel pada produk PCR dari gen ALDH2. Penelitian ini membuktikan bahwa 70 subyek (70\%) memiliki alel ALDH2 wild type, sedangkan 29 (29\%) subyek dengan alel ALDH2 yang atipik heterozigot dan hanya 1 (1\%) yang atipik homozigot. Dapat disimpulkan bahwa frekuensi alel ALDH2 yang atipik pada orang Indonesia (31/200) lebih tinggi daripada frekuensi tersebut pada orang Kaukasoid (hanya sekitar 5-10\%), namun lebih rendah dibandingkan dengan frekuensi pada orang Mongoloid (40-50\%). Hal ini mungkin berkaitan dengan keanekaragaman etnik yang dijumpai pada populasi Indonesia. (Med J Indones 2002; 11: 135-42)
\end{abstract}

\begin{abstract}
Aldehyde dehydrogenase $(A L D H)$ plays a pivotal role in the alcohol metabolism. Decreased activity of ALDH enzyme has more influence on the hypersensitivity to alcohol than of alcohol dehydrogenase. ALDH enzyme exists in several isozymes. Among these isozymes, ALDH 2 is a major isozyme that has a very high affinity for acetaldehyde. Recent studies suggested that the deficiency of ALDH2 may be inherited. Functional polymorphism of ALDH2 gene has been observed in a nucleotide of the $487^{\text {th }}$ codon. In the atypical gene, this codon consists of $\underline{A} A A$ nucleotides for lysine, instead of $\underline{G A A}$ for glutamic acid in the wild type gene. In this study, we have analyzed the genetic polymorphism of ALDH2 gene among 100 Indonesian students using genomic DNA extracted from hair roots. Polymerase chain reaction $(P C R)$ and restriction fragment length polymorphism (RFLP) methods were performed for this purpose. Three oligonucleotide primers were designed for two steps PCR. The reverse primer $R$ was intentionally constructed not to be $100 \%$ complementary to the template strand, to generate a restriction site for Eco RI within the variable nucleotide in the PCR product of ALDH2 gene. This study indicates that 70 subjects (70\%) have wild type, 29 (29\%) atypical heterozygote and only 1 (1\%) atypical homozygote ALDH2 alleles. Conclusively, the atypical ALDH2 allele frequency in Indonesians (31/200) is higher than in Caucasoids (only about 5-10\%), but less than in Mongoloids (40-50\%). This may be due to the diverse ethnics of Indonesian population. (Med J Indones 2002; 11: 135-42)
\end{abstract}

Keywords: alcohol hypersensitivity, genetic polymorphism, aldehyde dehydrogenase-2 (ALDH2) gene

Aldehyde dehydrogenase (ALDH), the principal enzyme responsible for oxidative metabolism of alcohol, exists in multiple, genetically determined molecular forms. Widely different kinetic properties in some of these isozymes account for the individual differences in alcohol sensitivity (Muramutsu et al.,

Department of Biochemistry, Faculty of Medicine, University of Indonesia, Jakarta, Indonesia
1995). Mitochondrial aldehyde dehydrogenase with a low Michaelis constant $(\mathrm{Km})$ for acetaldehyde, $\mathrm{ALDH} 2$, is a major isozyme that can most efficiently convert acetaldehyde, a toxic metabolite of ethanol, into acetic acid in the liver. Deficiency of ALDH2 activity, mostly found in Oriental people (Japanese and Chinese), leads to a high steady-state level of acetaldehyde in the blood after alcohol consumption. This accounts for the increased sensitivity to alcohol. Thus, much less ethanol is required to produce 
vasodilatation that results in facial flushing and rapid heart rate than is required to achieve the same effect in Europeans (Crabb et al., 1989).

Recent human genetic studies suggested that a predisposition to high alcohol sensitivity may be inherited. Functional polymorphisms have been observed at various genes encoding ALDH. Four genes which encode four different ALDH isozymes have been cloned and characterized at present time. The coding nucleotide sequences, and organization of introns and exons of theses genes have been elucidated (Yoshida, 1992). The ALDH1 gene encodes the major cytosolic ALDH1, existing in the liver and other tissues, with a lower affinity (high $\mathrm{Km}$ ) for acetaldehyde. The genetic deficiency of this isozyme was found at a low frequency $(<<10 \%)$ in both Caucasians and Orientals. The ALDH2 gene encodes the major liver mitochondrial ALDH2 enzyme which has a very high affinity for acetaldehyde. The high alcohol sensitivity has been attributed mainly to a highly prevalent polymorphism in ALDH2 gene. The atypical ALDH2 allele which is very common in Orientals, both homozygous and heterozygous, generates a decreased ALDH2 enzyme activity. Among the ALDH2-deficient individuals, the atypical homozygous was obviously more hypersensitive to alcohol than the heterozygous (Takeshita et al., 1994). Individuals possesing this abnormal ALDH2 gene have tendency not to be habitual drinkers, and have a markedly reduced risk in developing alcoholism and alcohol-related liver diseases (Morimoto and Takeshita, 1996; Agarwal, 1997). The ALDH3 gene produces a cytosolic ALDH3 isozyme existing in the stomach and liver carcinoma but hardly in normal liver. The ALDH3 locus is polymorphic in Orientals and presumably other population (Yoshida, 1994). The ALDH5 gene, which is expressed in testis and liver, is highly polymorphic in both Caucasians and Orientals (Yoshida, 1992).

Here, we focus to analyze only the polymorphism of ALDH2 genotype with regard to its essential role in alcohol sensitivity. There are many studies analyzing the polymorphism of the human liver ALDH2genotype in 21 different populations comprising Mongoloid (especially Japanese and Chinese), Caucasoids and Negroids. The atypical ALDH2 gene was found to be extremely rare in Caucasoids, Negroids, Papua New Guineans, Australian Aborigines and Aurocanians (South Chile). In contrast, this mutant gene was found to be widely prevalent among the Mongoloids (Goedde et al., 1992).
Although Oen et al. (unpublished result, 1989) in our laboratory have studied that the acetaldehyde dehydrogenase enzyme deficiency in Indonesian students is the cause of high sensitivity against alcohol, but until now, there is no data about the distribution of the genetic polymorphism of aldehyde dehydrogenase gene in Indonesian population. Indonesian population consists of many diverse and distinct ethnics including Chinese ethnic. In this study, we analyze the genetic polymorphism of ALDH2 gene among 100 students at Faculty of Medicine, University of Indonesia using the polymerase chain reaction (PCR) and restriction fragment length polymorphism (RFLP) methods. Since this population represents a diverse Indonesian population, the study will provide more information about diversity of human genome in Indonesian. However, further studies are required to compare specifically aldehyde dehydrogenase gene polymorphism in different ethnics in Indonesian.

\section{MATERIAL AND METHODS}

\section{Isolation of human genomic DNA}

DNA-samples were provided from hairs of 100 students (ages about 20 years old) at Faculty of Medicine, University of Indonesia. According to the ethical procedures, before taking the hair-samples the students were well-informed about purpose and procedures of the research. The isolation of human genomic DNA from hair was performed as follows. 6 hairs were cut about $0,5-1 \mathrm{~cm}$ from bottom including their roots and placed in a $1.5 \mathrm{ml}$ tube containing $50 \mu \mathrm{l}$ of hair buffer $(50 \mathrm{mM} \mathrm{KCl}, 10 \mathrm{mM}$ Tris $\mathrm{pH} 9.0,1.5$ $\mathrm{mM} \mathrm{MgCl} 2,0,5 \%$ Tween-20, $10 \mu \mathrm{g}$ Proteinase $\mathrm{K}$ ). The reaction was incubated for 1 hour at $55^{\circ} \mathrm{C}$ and finally boiled for $10 \mathrm{~min}$ at $95^{\circ} \mathrm{C}$. The concentration and purity index of DNA was determined using spectrophotometer at $260 \mathrm{~nm}$ versus $280 \mathrm{~nm}$.

\section{Polymerase Chain Reaction (PCR)}

The oligonucleotide primers were designed by computer based on nucleotide sequences of ALDH2 gene. Since total genomic DNA without prior restriction was used as a DNA sample, the PCR-analysis of ALDH2 gene should be performed twice. Therefore, we used three oligonucleotide primers (F1, F2 and R). Sequences of the primers are shown in figure 1. 


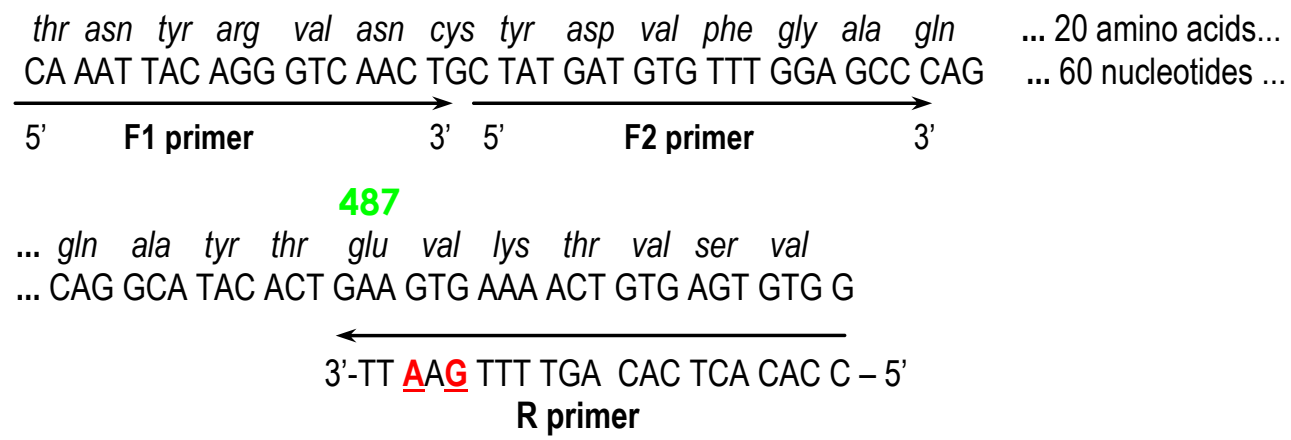

Figure 1. Sequences of oligonucleotide primers designed for PCR-analysis of ALDH2-gene

The forward primers F1 and F2 are complementary to the same template strand, while the reverse primer $\mathrm{R}$ is complementary to the other strand. $\mathrm{R}$ primer contains 2 nucleotides ( $\underline{A} A \underline{G})$ which are not complementary to the codon for valine ( $\underline{G T} \underline{G})$ on the template strand. This construction was intentionally designed to generate a restriction site for EcoRI (GAATTC) in the PCR product.

As described above, the optimal PCR should be performed in two steps PCR. The first PCR (PCR I) was performed, as follows. At first, the master mix of reagents containing $1 X$ PCR buffer $(10 \mathrm{mM}$ Tris $\mathrm{HCl}$, $\mathrm{pH} 8,3,50 \mathrm{mM} \mathrm{KCl}, 1.5 \mathrm{mM} \mathrm{MgCl}_{2}, 0,01 \%$ w/v gelatin), 50 pmol $\mathrm{F} 1$ primer, 50 pmol R primer, $1 \mu \mathrm{l}$ dNTP Mix (Promega), 1,25 U AmpliTaq DNA Polymerase (Applied Biosystems) and sterile aquabidest, was prepared for all samples. Then, $45 \mu \mathrm{l}$ of the master mix were aliquotted to the individual PCR tubes $(0.2 \mathrm{ml}) .5 \mu \mathrm{l}$ of human genomic DNA isolated from hair (ca. 2,5 $\mu \mathrm{g}$ DNA) were subsequently added in the tube. The reaction mixture with total volume of $50 \mu \mathrm{l}$ was gently mixed. Finally, ALDH2 gene of the human genome was amplified in a DNA thermal cycler (Perkin Elmer 2400). PCR process began with a 5 min initial template denaturation step at $94^{\circ} \mathrm{C}$, then start cycling for 30 times. Each cycle consists of a 30 -s melting step at $94^{\circ} \mathrm{C}$, a 30 -s primer annealing step at $53^{\circ} \mathrm{C}$ and a $30-\mathrm{s}$ primer extension step at $72^{\circ} \mathrm{C}$. The last cycle was followed by the $7 \mathrm{~min}$ final extension step at $72^{\circ} \mathrm{C}$. The second PCR (PCR II) was performed as follows.
The master mix of reagents for all samples was first prepared as described for PCR I, except for F2 primer, instead of F1 primer in the master mix of PCR I. $49 \mu \mathrm{l}$ of master mix were aliquotted into the new PCR tube. One $\mu \mathrm{l}$ of PCR I product was then added to give the total volume of $50 \mu \mathrm{l}$. The PCR process was also performed as described for PCR I.

\section{RFLP-Analysis of ALDH2 gene}

To analyze RFLP of ALDH2 gene, about $10 \mathrm{U}$ of restriction endonuclease Eco $R I$ were added to $25 \mu \mathrm{l}$ of every PCR II product. The restriction reaction (30 $\mu \mathrm{l}$ ) also containing $3 \mu \mathrm{l}$ of $10 \mathrm{X}$ EcoRI buffer, was incubated for 2 hours at $37^{\circ} \mathrm{C}$. Electrophoresis were performed using $10 \%$ polyacrylamide gel in TAE buffer, as recently described (Wanandi, 1993). About $3 \mu \mathrm{l}$ of sample buffer containing $1 \mathrm{X}$ TAE buffer and bromphenolblue (BPB) were added to $25 \mu \mathrm{l}$ of PCR II product, $30 \mu \mathrm{l}$ of restriction reaction and $1 \mu \mathrm{l}$ DNA Marker (pUC 18/MSpI), respectively. $35 \mu \mathrm{l}$ of total volume samples were pipetted to the well. Electrophoresis was run at $100 \mathrm{~V}$ for about 2.5 hours. The gel was stained with $0.02 \%$ ethidium bromide for about 2 minutes and destained twice with aquadest. The results were visualized using UV-Transiluminator and documented using Polaroid Documentation System. DNA fragments of $100 \mathrm{bp}$ and/or $80 \mathrm{bp}$ bands, respectively, were determined and compared to the bands of DNA Marker. The scheme of the whole procedures is shown in figure 2 . 


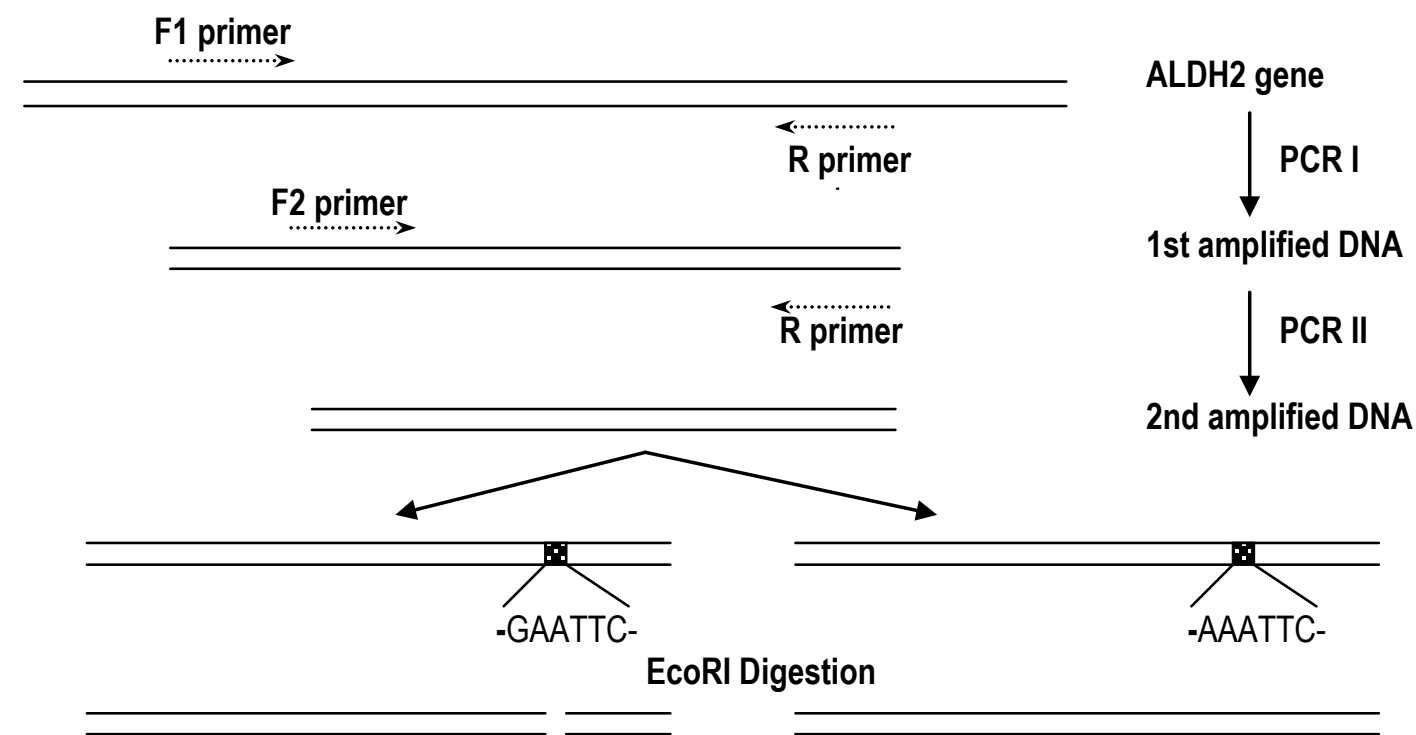

Polyacrylamide gel electrophoresis

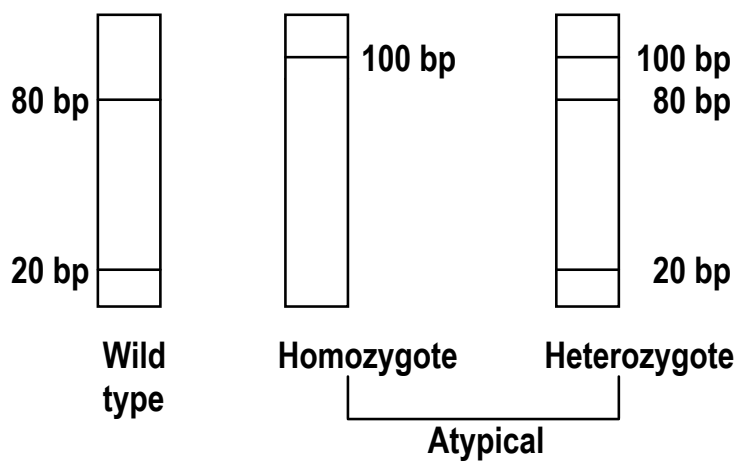

Figure 2. Scheme of RFLP-Analysis of ALDH2-gene using PCR technique and EcoRI digestion.

\section{RESULTS}

Human genomic DNA of 100 hair-samples from 100 students were isolated as described above. Average concentration of isolated total genomic DNA is 0.5 $\mu \mathrm{g} / \mu \mathrm{l}$ and average purity index is 1.5 (data not shown).

Figure 3 shows the electrophoresis result of PCRamplification of ALDH2 gene from several DNA samples. The $100 \mathrm{bp}$ PCR II product is specific for ALDH2 gene, since lane 7 containing no DNA could not produce any signal.
The result of Eco RI digestion of PCR product of ALDH2 gene is shown in figure 4. Lane 1 was a 100 bp PCR II product without Eco RI digestion. This restriction could generate several possibility, i.e.: 100 bp band (no restriction), 80 bp band (complete restriction; lanes 2-8 and 10-12) as well as $100 \mathrm{bp}$ and 80 bp bands (partial digestion; lanes 9, 13 and 14), respectively. These correspond to atypical homozygote, wild type and atypical heterozygote ALDH 2 genes, respectively. The 20 bp band which should appear together with the $80 \mathrm{bp}$ band could not be demonstrated in this gel, since this band is smaller than the bromphenol blue dye. 


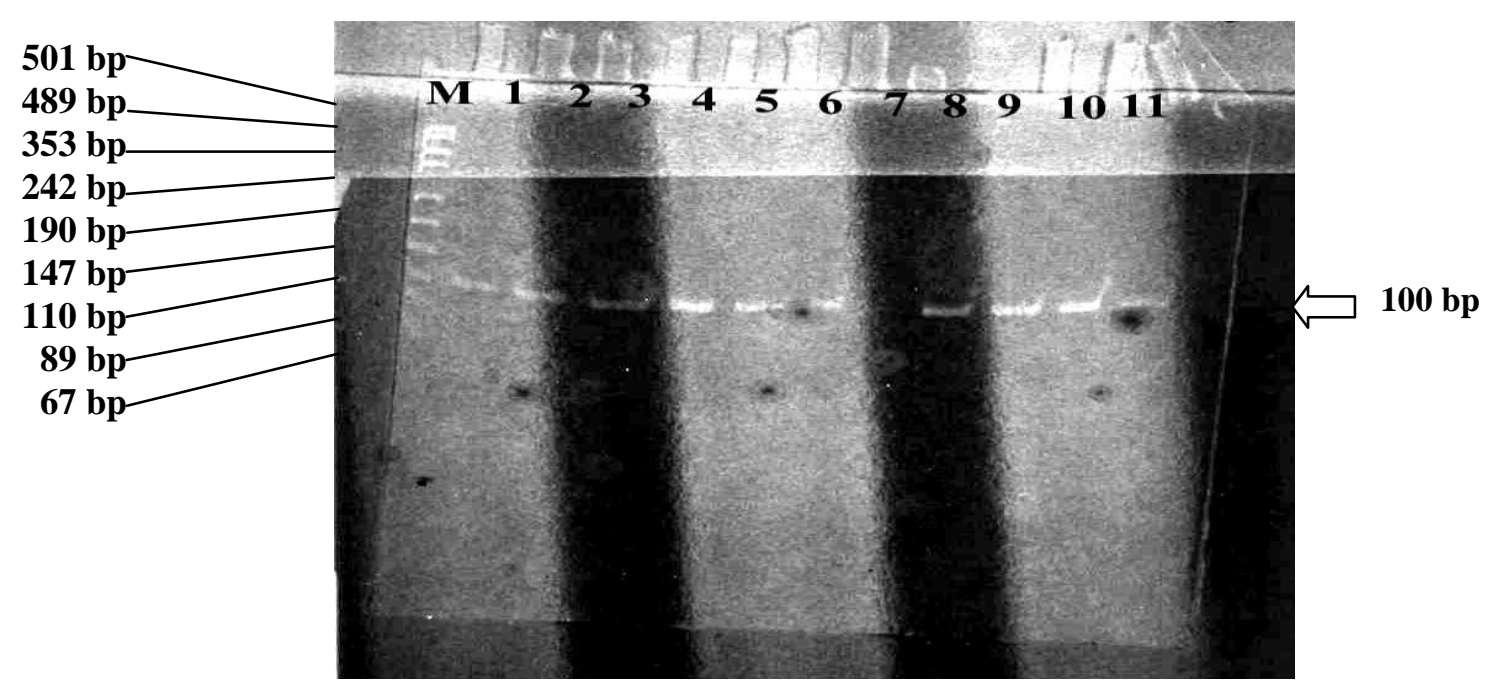

Figure 3. Electrophoresis of Polymerase Chain Reaction (PCR) result of ALDH2 gene. M: DNA Molecular Weight Marker (pUC/Msp I); Lanes 1-6, 8-11: PCR product (100 bp) from different DNA samples; Lane 7: Negative Control (no DNA sample).

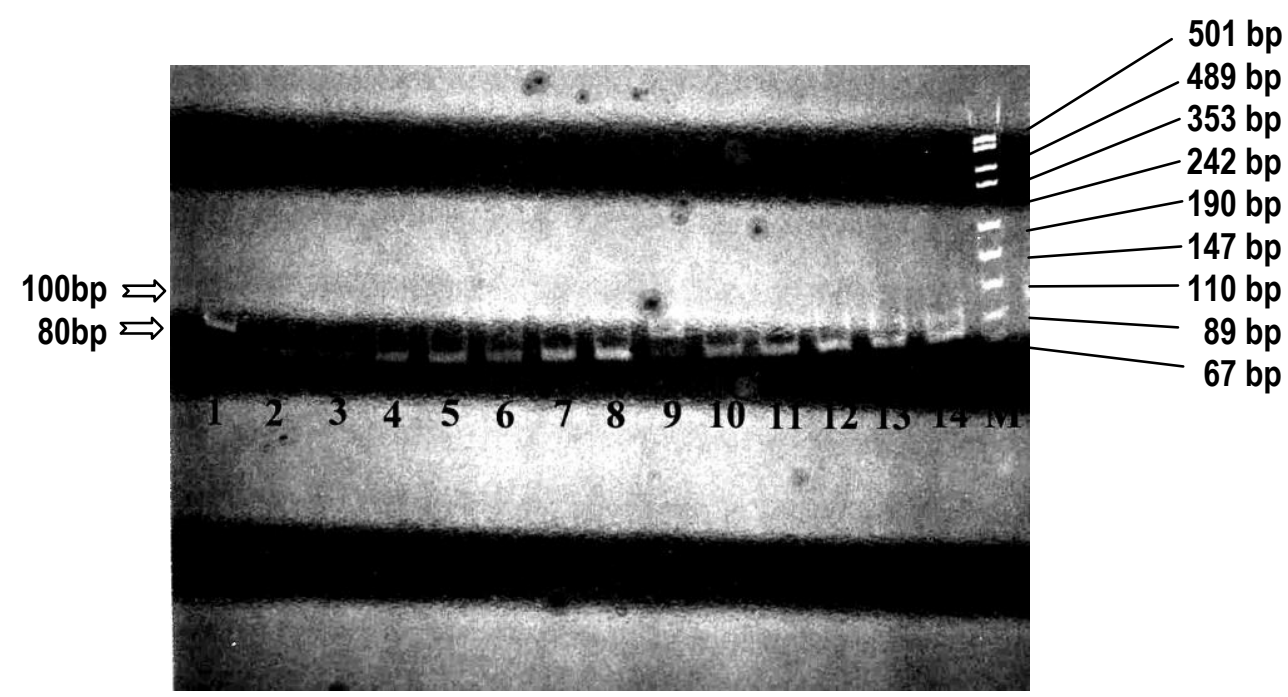

Figure 4. Electrophoresis of PCR-amplification result of ALDH2-gene after Eco RI digestion. M: DNA Molecular Weight Marker (pUC/Msp I); Lanes 2-14: different PCR product after Eco RI digestion; Lane 1: PCR product prior to Eco RI digestion (100 bp) 
Figure 5 also shows the RFLP-Analysis of ALDH2 gene. Lane 13 was the only sample from 100 Indonesian subjects which obviously generates a 100 bp band after Eco RI restriction of PCR II product, indicating that this sample contains an atypical homozygote ALDH2 gene. No signal could be detected in lane 4 . This may be due to the low purity index of the DNA sample $(0,43)$.
Conclusively, among 100 Indonesian people, 70 $(70 \%)$ has a wild type and $30(30 \%)$ has an atypical ALDH2 gene. Furthermore, among this 30 atypical gene, 96,7\% (29 subjects) are heterozygous while only $3,3 \%$ ( 1 subject) is homozygous (Figure 6).

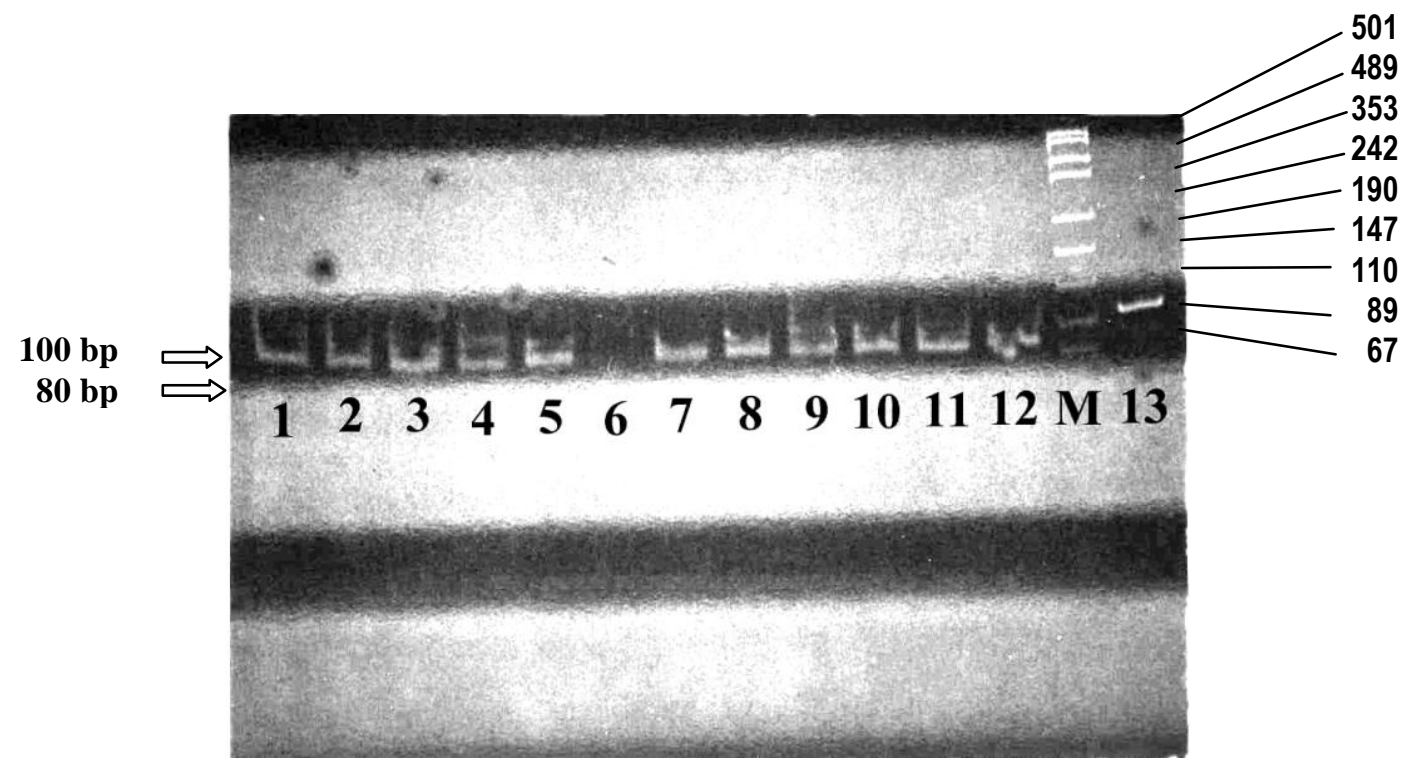

Figure 5. RFLP-Analysis of ALDH2 gene using PCR technique and Eco RI digestion.

M: DNA Molecular Weight Marker (pUC/Msp I); Lanes 1-13: PCR product from different DNA samples after Eco RI digestion; Lanes 1-3, 7,8,10-12: Wild type (80 bp); Lanes 4 and 9: Atypical heterozygote (100 and 80 bp); Lane13: Atypical homozygote ALDH2 gene (100 bp); Lane 6: No PCR product could be detected.

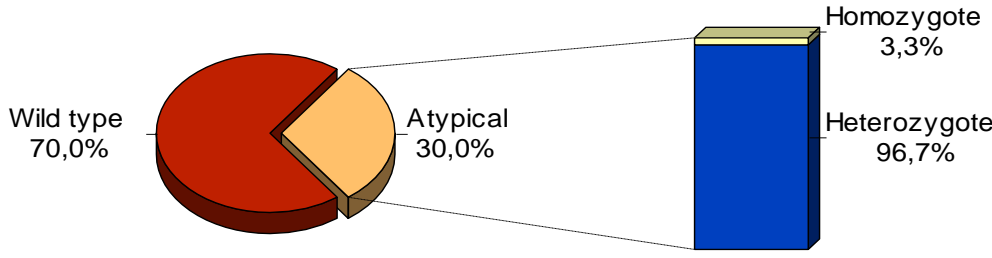

Figure 6. Distribution of wild type and atypical (homozygote and heterozygote) ALDH2 gene in 100 Indonesian sample 


\section{DISCUSSION}

ALDH2 enzyme consists of 517 amino acids. Recent studies suggested that individu with hypersensitivity against alcohol has a variation in the ALDH2 gene. G nucleotide in the $487^{\text {th }}$ codon (GAA) for glutamic acid is substituted to A nucleotide. This variation leads to a substitution of glutamic acid to lysine (AAA) in this position (Figure 7). Since this glutamic acid is very essensial for the ALDH2 enzyme activity, change of this amino acid causes a disorder of alcohol metabolism.

In this study, we determined the ALDH2 gene variation and analyzed the distribution of genetic polymorphism of this gene among 100 Indonesian subjects. For this purpose, three oligonucleotide primers for two steps PCR were designed based on published cDNA of ALDH2 gene including the variable nucleotide for codon 487 (Fig. 7). To demonstrate the existence of this nucleotide variation, RFLP method must be performed for the PCR product of ALDH2 gene. Nevertheless, we could not find any restriction site for any restriction endonuclease in the region of this codon. Thus, the reverse primer $\mathrm{R}$ was intentionally constructed not to be $100 \%$ complementary to the template strand, to further generate a restriction site for Eco RI (GAATTC) in the PCR product within this region (Fig. 1). However, the hybridization of this primer to the template is not influenced.

We could not demonstrate any PCR product from the first PCR (data not shown). This result may be correspond to the use of total genomic DNA without prior restriction. Therefore, the PCR-analysis of ALDH2 gene should be performed twice. The second PCR obviously resulted in a specific 100 bp amplification product, since the sample without DNA could not produced any signal (Fig. 7) and Eco RI could successfully digest this PCR product (Fig. 4 and 5). But, this PCR-Analysis without Eco RI restriction could not demonstrate any variation of ALDH2 gene.
Following Eco RI restriction, single $80 \mathrm{bp}$ band on the polyacrylamide gel indicated the normal (wild type) ALDH2 alleles. The atypical (mutant) ALDH2 gene could not be digested by this enzyme, therefore, the $100 \mathrm{bp}$ could exist as a single band in the homozygote, or in combination with the $80 \mathrm{bp}$ in the heterozygote one (Fig. 4 and 5).

This research indicates that $70 \%$ of Indonesian subjects are not hypersensitive to alcohol and 30\% subjects with the atypical allele(s) of ALDH2 gene, both homozygous and heterozygous status, possess a decreased ALDH2 activity. According to Takeshita et al. (1994), the atypical homozygous (only 1 subject) should be more hypersensitive to alcohol than the heterozygous (29 subjects). Interestingly, most of the $30 \%$ subjects with atypical allele have never realized their sensitivity to alcohol. In contrast to many Orientals, the alcohol sensitivity reactions rarely occur in most of Indonesians, even though the distribution of the atypical / mutant ALDH2 allele is rather high. This may due to the Moslem religion of the most population and may contribute to the lower tendency to drink alcohol excessively (compared with Wall et al., 1992; Muramutsu et al., 1995). In fact, the only subject with homozygote for the mutant gene has never consumed enough alcohol to show the sensitivity responses. Here, we suggest that the polymorphism of ALDH2 genotype in Indonesians is more highly prevalence than in Caucasoids (only about 5-10\%; Goedde et al., 1992), but less than in Japanese men (4050\%; Tsuritani et al., 1995). This condition may be due to the diverse ethnics of Indonesian population.

Further studies are required to analyze family inheritance of the subject with atypical homozygote ALDH2 gene and to compare specifically the ALDH2 gene polymorphism in different ethnics in Indonesian. We hope that these serial studies could provide more informations about diversity of human genome in Indonesian.

\section{7 \\ ... gln ala tyr thr glu val lys thr val ser val \\ ... CAG GCA TAC ACT GAA GTG AAA ACT GTG AGT GTG G Wild type \\ 487 \\ ... gln ala tyr thr lys val lys thr val ser val \\ ... CAG GCA TAC ACT AAA GTG AAA ACT GTG AGT GTG G Variation}

Figure 7. Nucleotide variation of ALDH2-gene at codon 487 for lysine, instead for glutamic acid in the wild type gene. 


\section{CONCLUSION}

The atypical ALDH2 allele frequency in Indonesians $(31 / 200)$ is higher than in Caucasoids (only about 5$10 \%$ ), but less than in Mongoloids (40-50\%). This may be due to the diverse ethnics of Indonesian population.

\section{ACKNOWLEDGEMENT}

This research was supported by International Toray Science Foundation (ITSF), Jakarta. The authors would like to extend our special thanks to dr. Djaja Surjaatmadja, PhD for his kindness to lend the PCR machine, UV-Transilluminator and Polaroid Documentation System, to drg. Dwirini Retno G. and to Rini Puspitaningrum, SSi. for technical support, and to Erna, Vita and Maskuroh for their help in preparing the report, as well as in providing the samples.

\section{REFERENCES}

1. Crabb DW, Edenberg HJ, Bosron WF, Li T-K. Genotypes for aldehyde dehydrogenase deficiency and alcohol sensitivity: The ALDH2 allele is dominant. J Clin Invest 1989;83:314

2. Goedde HW, Agarwal DP, Fritze G, Meier-Tackmann D, Singh S, Beckmann G, et al. Distribution of ADH2 and
ALDH2 genotypes in different populations. Hum Genet 1992;88(3):344-6

3. Morimoto $\mathrm{K}$, Takeshita $\mathrm{T}$. Low $\mathrm{Km}$ aldehyde dehydrogenase (ALDH2) polymorphism, alcohol-drinking behavior, and chromosome alterations in peripheral lymphocytes. Environ Health Perspect 1996; 104 Suppl 3:563-7

4. Muramutsu T, Wang ZC, Fang YR, Hu KB, Yan H, Yamada K, et al. Alcohol and aldehyde dehydrogenase genotypes and drinking behavior of Chinese living in Shanghai. Human Genet 1995;96(2):151-4.

5. Takeshita $\mathrm{T}$, Morimoto $\mathrm{K}$, Mao $\mathrm{X}$, Hashimoto $\mathrm{T}$, Furuyama J. Characterization of the three genotypes of low $\mathrm{Km}$ aldehyde dehydrogenase in a Japanese population. Hum Genet 1994;94(3):217-23

6. Tsuritani I, Ikai E, Date T, Suzuki Y, Ishizaki M, Yamada Y. Polymorphism in ALDH2-genotype in Japanese men and the alcohol-blood pressure relationship. Am J Hypertens 1993;8(11):1053-9

7. Wall TL, Thomasson HR, Schuckit MA, Ehlers CL. Subjective feelings of alcohol intoxication in Asians nuywith genetic variations of ALDH2 alleles. Alcohol Clin Exp Res 1992;16(5):991-5

8. Yoshida A. Molecular genetics of human aldehyde dehydrogenase. Pharmacogenetics 1992; 2(4):139-47

9. Yoshida A. Genetic polymorphisms of alcohol metabolizing enzymes related to alcohol sensitivity and alcoholic diseases. Alcohol Alcohol 1994;29(6):693-6

10. Wanandi SI. Isolierung und Charakterisierung des für die spezifische Expression von U6-Genen in Säugetieren benötigten Transkriptionsfaktors PBP (Proximales Sequenzelement bindendes Protein) [dissertation]. Marburg (Germany): Philipps Univ.;1993. 
